\title{
THE ROLE OF METACOGNITIVE INSTRUCTION IN DEVELOPING ESL/EFL LISTENING ABILITIES: A THEORETICAL AND EMPIRICAL REVIEW
}

\author{
Ani Fiani ${ }^{1}$ \\ STKIP-PGRI Lubuklinggau \\ annie_fiani@yahoo.com ${ }^{1}$
}

Submit, 23-11-2018 Accepted, 30-12-2018 Publish, 30-12-2018

\begin{abstract}
Due to metacognition, as a psychological concept, has been a focus of educational researchers and become a potential to empower students to improve their own learning; increase the meaningfulness of learning, especially among students who are having problems in learning; and become successful learners, the present paper implicatively investigates the possible role of metacognitive instruction in developing ESL/EFL listening abilities among students by providing theoretical and empirical foundations drawn from the literature. To elicit the purpose of this article, the literature study was used. This study reviewed several recent research papers in the last 10 years related to the implementation of metacognitive instruction in order to elicit the information of the possibilities in developing ESL/EFL students' listening comprehension abilities. Based on a detailed analysis and review of the research articles, there were some themes related to the possibility role of implementing the instruction not only developing ESL/EFL listening abilities, but also metacognitive knowledge and metacognitive awareness. Moreover, the instruction enables ESL/EFL students to increase their awareness of the listening process by improving richer metacognitive knowledge about themselves as listeners, the nature and demands of listening tasks, and listening strategies. This instruction they may encourage them to have an ability to regulate their own learning in and outside ESL/EFL classrooms. Therefore, based on the literature review and analysis above, ESL/EFL teachers will regard the important role of metacognition and attempt to implement the instruction as an alternative of effective teaching ways to develop ESL/EFL students' listening abilities in and outside the classroom independently, particularly in the context of higher education in Indonesia.
\end{abstract}

Keywords: metacognition, metacognitive awareness, metacognitive instruction, listening abilities 


\section{INTRODUCTION}

In the current time, the development of technology has become challenges for all people in the world, including ESL/EFL students. They should be able to follow and learn not only by their teachers, but also by themselves. It means that they should be able to learn independently in and outside the language classrooms. One of the criteria to become independent learners is students should have metacognitive abilities to plan, monitor or regulate and evaluate their learning so that they are able to improve their language learning outcomes. They are easy to elicit all of the information they need. Therefore, in ESL/EFL listening, they should have these abilities to enhance their listening abilities as one prerequisite of successful language learners although this topic has not been investigated yet in Indonesian context, particularly in EFL listening contexts.

ESL/EFL listening is an indispensable skill for language learning due to the most frequently used in normal daily life and playing a significant role in the development of other language skills (Richards, 2008:3; Rost, 2002:1). Effective listening comprehension skills support students' language learning success (Goh, 2008:195; Vandergrift and Goh, 2012:4). The importance of this skill is based on a view of its role in second language acquisition (SLA). It starts from Krashen's Input Hypotheses (1985:90) that makes a claim that comprehensible input is the primary source of language acquisition. Although there were various criticisms to his hypothesis, most of SLA experts agree that such input has a critical role in language learning.

Previously, this skill had been considered a passive skill and its core purpose was only to extract or understand meaning from text. However, expanding to this role, listening is now also regarded as a skill that can support the growth of other aspects of language knowledge such as speaking or reading speed (Chang and Millett, 2015:23), linguistics elements (van Zeeland and Schmitt, 2013:67; Vidal, 2011:25), and so forth. Thus, this skill has been a crucial skill to develop and can be taught integratedly (e.g. in a secondary level and ESP context) or discretely as a particular subject (e.g. in a tertiary level in English department).

In Indonesia, it has been a crucial skill to develop. It can be seen from the role of listening in the development of EFL curriculum. Long before the 2004 English curriculum set up, the primary purpose of EFL teaching was to prepare students with abilities in reading English texts. However, the current EFL instruction attempts to meet the demands to master all the four language skills listening, reading, writing, and speaking (Agustien, Anugerahwati, \& Wahidah, in Cahyono and Widiati, 2009:195). Even, the important of this skill still continues in the current EFL curriculum, the 2013 English curriculum. This skill can be taught integratedly or discretely. 
However, in fact, in learning this skill, not all of the students succeed. They are often faced with difficulties such as how fast a person is speaking, words used, and limited background knowledge of the students. Further explanation, this skill is generally regarded as a difficult skill and as a source of anxiety for them (e.g. Graham, 2006:78). They associate those problems to what they perceive as their low listening ability or difficult listening texts or tasks. As Graham (2006:178) points out, "such association indicate a sense of passivity and helplessness in language learners which could easily result in they becoming demotivated, resigned to being less effective listeners". In these cases, offering more listening texts or tasks to the students who find listening difficult will most likely add their sense of failure (Field, 2002:45; Graham, 2006:34) and thus O'Malley, et al (1985:37) argue that those students as "learners without direction or opportunity to review their progress, accomplishments and future direction".

Generally, there are several problems in ESL/EFL listening classroom contexts such as teachers still tend to focus on the outcome/product of listening and they do not include sufficient guidance in the process of learning to become more successful listeners (Vandergrift and Goh, 2012:4-5). These problems also happened in Indonesian contexts. It can be seen from the development of EFL listening abilities, compared with other language skills, is still low among students in the current era. Then, in EFL listening classes, teachers tend to test rather than teach them the way how to use the effective ways to develop their own learning in and outside the classrooms. Most of them do not succeed yet in learning this skill. They perceive that this skill is generally regarded as a difficult skill and as a source of anxiety so that in learning the skill, they tend to be passive and do not initiate to improve it due to they do not know yet how to use appropriate or effective ways to enhance their learning in listening by themselves.

As suggested by several listening experts (Mendelshon, 1994, 1995, 1998; Rost, 2005:87), to overcome those problems, the ESL/EFL students should be taught how to listen by making them aware of the mental processes that are involved in listening and equipping them with effective listening strategies. In addition, they should be made conscious of the need to focus on using appropriate strategies of metacognitive knowledge (planning, monitoring, and evaluating) about listening as well as regulate the proper metacognitive strategies for listening (Goh, 2000, 2002; Vandergrift, 2002, 2003, 2004; Vandergrift and Goh, 2012:12). In short, ESL/EFL students have to develop their knowledge and regulation of cognition in learning listening to achieve their learning goals as successful learners.

Developing ESL/EFL students' metacognition promotes them an awareness of the learning process and strategies that leads to succeed in their language learning. They will understand their own thinking and learning process, 
as well as their strengths and weaknesses in listening skills. Then, they are more likely to select and apply learning strategies appropriately, plan how to set a learning goal, monitor their own learning progress, find solutions to problems encountered, and evaluate themselves in completing a learning task, especially in a listening task (Zhang and Goh, 2006:37). The use of these strategies activates their thinking and leads to improve their performance in common (Anderson, 2002:94).

Therefore, as a preliminary study to find the possibilities role of metacognitive instruction in ESL/EFL listening contexts, the aim of this current article attempts to provide theoretical and empirical review of studies done in investigating the role of metacognition in ESL/EFL listening skills.

\section{LITERATURE REVIEW}

Metacognition was initially introduced by Flavell (1979) and Brown (1980). Then, in language learning, Wenden (1987) is a pioneer who implemented this concept. He articulated that metacognition has a crucial role in developing learner autonomy and differentiating cognitive processes between students. This term has been described as 'a critical analysis of thought', 'knowledge and cognition about cognitive phenomena, or simply 'thinking about thinking' (Flavell, 1979).

Then, Hacker, Dunlosky, and Graesser (2009, ) expand this concept as one's ability to think about one's own thinking or cognition, and, by extension, to think about how one processes information for a range of purposes and manage the way one does it. Therefore, metacognition is not only one's knowledge of cognition but also one's regulation of cognition.

Metacognition generally includes two main components, knowledge of cognition and regulation of cognition (Schraw and Moshman, 1995:600). Knowledge of cognition deals with what students know about their cognition and is categorized into three aspects, personal knowledge, task knowledge, and strategy knowledge (Flavell, 1979:906). Firstly, personal knowledge is knowledge about how one learns and the various factors affect that one's learning. It is talking about what students know about themselves as learners and the beliefs students have about what leads to success or failure in their learning. The second is task knowledge, which is knowledge about the purpose, demands, and nature of learning tasks, for examples listening tasks. The last is strategy knowledge. It involves knowledge about effective strategies for learning tasks and knowledge about how best to approach the learning tasks.

Besides that, another component is regulation of cognition. It involves at least three components - planning, monitoring, and evaluation (Schraw and Moshman, 1995:600). Planning is a process for selecting appropriate strategies 
and allocating resources. It includes goal setting, activating relevant background knowledge, and budgeting time. The second component is monitoring. It provides the self-testing skills necessary to control learning at both the local and global levels. Then, the last is evaluation. It refers to appraising the products and regulatory processes of student's learning such as re-evaluating one's goals, revising predictions, and . Typical examples of this component are re-evaluating one's goals, revising predictions, and consolidating one's learning achievements.

Regarding the explanation of the concept above, it is important to apply this term as knowledge and regulation of cognition, into action to develop students' metacognitive awareness (e.g. Wenden, 1987). Metacognitive awareness means being aware of how one thinks. This development can be described as conscious development in one's metacognitive abilities such as the move to greater knowledge, awareness and control of one's learning, selecting appropriate learning strategies, monitoring the learning progress, solving the problems during the process of learning, analyzing the effectiveness of learning strategies, and changing learning behaviors and strategies when necessary (Ridley et al, 1992:45).

As stated by Wenden (in Coskun, 2013:36-37), students who have metacognitive abilities seem to have the following benefits such as 1) they are more strategic learners; 2) their rate of progress in learning as well as the quality and speed of their cognitive engagement is faster; 3) they are confident in their abilities to learn; 4) they do not hesitate to get help from peers, teachers, or family when needed; 5) they provide accurate assessments of why they are successful learners; 6) they think clearly about inaccuracies of why they are more successful learners; 7) their tactics match the learning task and adjustments are made to reflect changing circumstances; and 8) they perceive themselves as continual/lifelong learners and can successfully adapt with new situations.

Particularly, in ESL/EFL listening context, metacognitive approach has been has been developed by several researchers such as O'Malley and Chamot (1990:153) who proposed CALLA model and Vandergrift and Tafaghodatari (2010:23) who suggested metacognitive instruction. These models have been implemented and examined in ESL/EFL listening contexts. These models can potentially improve students' awareness of their listening and learning process and develop students' ability to use appropriate learning strategies. In ESL contexts such as in Malaysia, the important role of metacognitive instruction has been investigated in reading (Pressley and Gaskin, 2006:23) and some indications of its benefits have also observed amongst weak ESL listeners (Goh and Taib, 2006:230).

Moreover, although research on metacognitive awareness about listening is still relatively new, there were a number of research studies that showed a significant association between metacognitive instruction and ESL/EFL listening performance. The use of metacognitive strategies lead to better listening performance in different 
contexts (e.g. Vandergrift, 2003:23; O’Malley and Chamot, 1990:67; Thomson and Rubin, 1996:56). A study of Vandergrift (2003:46) trained ESL students in the use of metacognitive strategies in beginner elementary school and university contexts in France. This study more focused on the advantages of predictions for successful listening, the place of collaboration with a partner for monitoring, and the confidence-building function for developing listening performance. O'Malley and Chamot (1990:153) trained intermediate high school ESL students received instruction in a metacognitive, a cognitive, and a socio-affective strategy. This study had three classes divided into two groups: a treatment group and two control groups (a group with instruction in a cognitive and a socio-affective strategy only and a group with no strategy instruction). The results showed that each daily test, the treatment group performed better than the control group, and that the metacognitive group had a better performance than the cognitive group on three of the four tests. In addition, another study has been conducted by Thomson and Rubin (1996:90). This study investigated the influence of metacognitive and cognitive strategy instruction on the listening comprehension performance of American university students learning Russian. The students' listening scores of the experiment group compared to the scores of the control group over a two-year period revealed that the students who received strategy instruction in listening to video-recorded text developed significantly over those who had received no strategy instruction at the end of the treatment.

\section{RESEARCH METHOD}

This current article reviews several recent research papers in the last 10 years related to the implementation of metacognitive instruction in order to elicit the information of the possibilities in developing ESL/EFL students' listening comprehension abilities. The theoretical and empirical review are based on Clark and Cresswell's (2010:79) definition. This study refers to "a written synthesis of journal articles, books, and other documents that summarizes and critiques the past and current state of information about a topic, organizes the literature into subtopics, and documents the background of the study".

In finding those relevant articles, a systematic search through several online sources such as ERIC (Educational Research Informational Center), Proquest, Google Scholar, Science Direct data base is conducted. Those articles were then selected based on the following criteria: 1) the researches published within the last 10 years; 2) the researches focused on the implementation of metacognitive instruction; and 3) the researches undertaken in English language classroom setting, particularly in ESL/EFL listening contexts. Moreover, those relevant studies are analyzed and reviewed to identify the possibility roles of the implementation of metacognitive instruction in ESL/EFL listening contexts. 


\section{FINDING}

Through a detailed analysis and review of the research articles, there are some themes related to the possibility role of implementing metacognitive instruction such as developing ESL/EFL listening abilities, metacognitive knowledge, metacognitive awareness. The influence of metacognitive instruction on listening comprehension performance has been demonstrated by ample evidence of current research studies in EFL contexts (i.e. Birjandi and Rahimi, 2012; Selamat and Sidhu, 2013; Rasouli, Mollakhan, and Karbalaei, 2013; Malik, Sarudin, Muhammad, and Ibrahim, 2013; Rahimirad, 2014; Wang, 2016).

Moreover, the implementation of metacognitive instruction is developing not only students' listening comprehension but also metacognitive knowledge and metacognitive strategy use (i.e. Malik, Sarudin, Muhammad, and Ibrahim, 2013; Wang, 2016).

\section{The development of listening comprehension abilities}

The research results from several research articles have indicated that metacognitive instruction could encourage students to develop their listening comprehension abilities. One of the few of empirical studies (Birjandi and Rahimi, 2012:505) highlighted the effect of metacognitive strategy instruction on EFL students' listening performance in Iran. This study used 62 students learning English translation and literature at Shahid Beheshti University and implemented metacognitive strategy instruction proposed by Vandergrift and Tafaghodatari (2010:34) and O'Malley and Chamot (1990:153). The result of statistical analysis indicated that the experimental group with the strategy training instruction significantly outperformed the control group with no instruction on the post-test measure.

Similarly, Selamat and Sidhu (2013:428) investigated the effect of metacognitive strategy training on lecture listening comprehension abilities of university students in Malaysia. This study included 34 first-year students from the faculty of education in a public university and collected the research data from the use of a questionnaire, a listening test, and semi-structured interviews. Those students were divided into two groups, the experimental and control group. The result revealed that students from the experimental group when listening to lectures in English scored higher in the listening tests.

Then, Rasouli, Mollakhan, and Karbalaei (2013:125) examined the effect of metacognitive listening strategy training on listening comprehension in Iranian EFL context. This study involved 120 intermediate students studying English in Zabansara English Institute in Gorgan, Iran. They were randomly divided into six intact classes and assigned to three experimental groups and other classes as control group. Students in the experimental groups were taught the metacognitive listening strategies included in Metacognitive awareness listening questionnaire based on CALLA instructional model proposed by Chamot and O'Malley (1994:90), but other 
classes as control group received no strategy instruction. In collecting data, this study implemented pre-test and post-test standardized measures and metacognitive listening strategy questionnaire. The result revealed that the metacognitive strategy training could advance Iranian EFL students from the beginning level to a higher level of listening comprehension.

Next, a study written by Malik, Sarudin, Muhammad, and Ibrahim (2013:57) investigated the effects of metacognitive listening strategy training on listening comprehension and strategy use of ESL learners. The participants of this study were 54 students and randomly assigned to two groups, 29 students in the experimental group and 25 students in the control group. The students in the experimental group were provided with a list of metacognitive strategies and their descriptions and were taught how to use them, while other students in the control group took the normal listening course. The findings revealed that students who underwent metacognitive listening strategy training performed slightly better than students in the control group. However, the difference was not statistically significant. Nevertheless, after the treatment, they had more strategy repertoire and used these strategies more frequently. It meant that they reflected the characteristics of good listeners.

Furthermore, Rahimirad (2014:1490) examined the impact of metacognitive strategy instruction on University students' listening performance in Iran. This study used 50 participants whose English proficiency around intermediate level. Those students were randomly assigned to experimental and control groups. The experimental group received the metacognitive strategy instruction based on the models suggested by Vandergrift and Tafaghodtari (2010:98) and O'Malley and Chamot (1990:130), whereas the control group received no strategy instruction. The result showed that the experimental group significantly outperformed the control group on the post-test.

The current study conducted by Wang (2016:85). This paper investigated the impact of a metacognitive approach to listening instruction on a Chinese university focused on students' listening proficiency and aspects of metacognitive knowledge. This study indicated that metacognitive instruction positively affect students' listening abilities and that it could contribute to their development in three components of metacognitive knowledge, namely person, task, and strategy knowledge.

\section{Metacognitive Knowledge}

Successful listening is often correlated with metacognitive knowledge and metacognitive regulation skills (Vandergrift and Goh, 2012:86). The implementation of metacognitive instruction in listening contexts has been examined to find out the impact of the instruction not only for the development of listening abilities but also the improvement of metacognitive knowledge. One of the empirical studies was conducted by Malik, Sarudin, Muhammad, and Ibrahim (2013:64). This study revealed that after the implementation of metacognitive instruction students were 
able to benefit the effective/appropriate listening strategies in helping them to improve their language learning success, especially in ESL/EFL listening contexts

Similarly, another research study was done by Wang (2016:85). This study investigated the impact of metacognitive instruction on Chinese University EFL students' listening abilities and metacognitive knowledge. Focusing on the effect of the intervention on three aspects of metacognitive knowledge, the findings reported that metacognitive instruction contributed to students' improvement in person, task, and strategy knowledge.

\section{DISCUSSION}

Based on the literature review and analysis above, some language educationists have discussed the rationale for incorporating metacognitive instruction into teaching listening comprehension (e.g. Vandergrift, 2004; Goh, 2008; Vandergrift and Goh, 2012). Goh (2008:195) assumed that "metacognitive instruction can potentially heighten learners' awareness of their listening and learning processes and develops learners' ability to use appropriate strategies". However, mixed findings of the research studies on the effects of metacognitive strategy instruction on listening performance have challenged the accuracy of this assumption.

A number of the above-mentioned previous research studies on implementing metacognitive instruction in teaching listening had showed that there was a positive effect on students' listening achievements. Then, other research studies revealed that the experience raises students' metacognitive knowledge about listening (e.g. Vandergrift, 2004:95) and increased students' understanding of the nature and the demands of listening and their confidence in completing listening tasks (Goh and Taib, 2006:230). Moreover, students who have metacognitive abilities seem to have some advantages such as more strategic learners, confident in their abilities to learn, and so forth.

However, a few studies have reported non-significant changes in listening performance (Seo, 2002:150) or strategy use and awareness (Chen and Huang, 2011:290) after the strategy instruction. The results have been attributed to both students' characteristics and contextual factors (Chen and Huang, 2011:245).

Although, there have been a few studies reported that non-significant changes in listening performance, for other above-mentioned studies showed support for the view that metacognition is significantly related to listening performance among students. There is a positive impact of the implementation of metacognitive instruction on listening performance. Both CALLA and metacognitive instruction as models of strategy instructions have been used in different contexts successfully. Thus, based on those promising findings, integrating metacognitive instruction into teaching listening comprehension need more investigations to settle the controversies (Goh, 2010:179). 
In Indonesian context, although the research studies of the implementation of metacognitive instruction have been investigated in English language learning such as reading (Mbato, 2013; Pammu, Amir, and Maasum, 2013), the effect of this instruction in EFL listening has not been found yet.

Mbato (2013:176) conducted a research focused on facilitating self-regulation in EFL reading classes through metacognitive approach. The results showed that the approach appears to have a promising future for Indonesian teachers and learners and supporting the development of self-regulated learning in students and assist them to gain a higher level of English language learning success.

Another study investigated by Pammu, et al $(2013 ; 363)$ reported about profiles of metacognitive reading strategies of the less proficient EFL learners. The findings revealed that there is a high level of metacognitive awareness for problem solving strategy but only at medium level for both global and support strategy. It meant that the less proficient EFL learners need the reading strategy instruction not only for the global analysis of texts, but also for the use of outside reference materials in order to generate their metacognitive awareness to enhance their proficiency level.

\section{CONCLUSION}

In conclusion, insight based on the theoretical and empirical review above can provide teachers and instructors with clear and explicit guidelines on how students can increase their autonomy in language learning, particularly in ESL/EFL listening. Regarding this, the teachers in Indonesia can use wide range of learning instructions and tasks that promote the implementation of metacognitive instruction as an alternative of effective teaching ways in their teaching in EFL listening classes to facilitate students with adequate learning strategies to enhance independent learning and become more successful listeners and conduct a research to find out the effect of metacognitive instruction in language learning, especially in listening skill and metacognitive knowledge.

\section{REFERENCES}

Anderson, N. J. (2002). The role of metacognition in second language teaching and learning. ERIC Digest.

Birjandi, P., \& Rahimi, A. H. (2012). The Effect of Metacognitive Strategy Instruction on the listening performance of EFL Students. Internationa Journal of Linguistics, 4 (2), 495-517.

Brown, A. L. (1980). Metacognitive development and reading. In R. J. Spiro, B. Bruce, and W.Brewer (Eds.), Theoreical issues in reading comprehension (pp. 453-482). Hillsdale, NJ: Lawrence Erlbaum Associates.

Cahyono, B. Y., \& Widiati, U. (2009). The teaching of EFL Listening in the Indonesian Context: The State of the art. TEFLIN Journal, 20 (2), 194211. 
Chang, C. -S., \& Millett, S. (2015). Improving reading rates and comprehension through audio-assisted extensive reading for beginner learners. System, 52, 91-102.

Chen, C. C., \& Huang, C. T. (2011). Raising EFL Collefe Students' Metacognitive awareness about listening. Paper presented at the NYS TESOL 41st Annual Conference, Melville, NY.

Clark, P., \& Cresswell, J. W. (2010). Designing and Conducting mixed methods research ( $2^{\text {nd }}$ Eds.). Thousand Oaks, CA: Sage.

Coskun, A. (2013). The effect of metacognitive strategy training on the listening performance of beginner students. Research on Youth and Language, 4(1), $35-50$.

Field, J. (2002). The changing face of listening. In methodology in language teaching: An anthology of current practice. J. Richards and W. Renandya (Eds). Cambridge: Cambridge University Press.

Flavell, J. H. (1979). Metacognition and cognitive monitoring: A new area of cognitive developmental inquiry. American Psychologist, 34, 906-911.

Goh, C. (2000). A cognitive perspective on language learners' listening comprehension problem. System, 28, 55-75.

Goh, C. (2002). Learners' self-reports on comprehension and Learning strategies for listening. Asian Journal of English Language Teaching, 12, 46-68.

Goh, C. (2008). Metacognitive Instruction for second language listening development: theory, practice and research implications. RELC Journal, 39(2), 188-213.

Goh, C. (2010). Listening as process: learning activities for self-appraisal and self-regulation. In N. Harwood (Ed.), Materials in ELT: Theory and Practice (pp. 179-206). Cambridge: Cambridge University Press.

Goh, C., \& Taib, Y. (2006). Metacognitive instruction in listening for young learners. ELT Journal, 60, 222-232.

Graham, S. (2006). Listening comprehension: the students' perspective. System: an International Journal of Educational Technology and Applied linguistics, 34, 165-182.

Hacker, D. J. Dunlosky, J., \& Graesser, A. C. (2009). Handbook of metacognition in Education. Mahwah, NJ. Erlbaum/Taylor \& Francis.

Krashen, S. (1985). The Input Hypothesis: issues and implication. London: Longman.

Malik, F. A., muhamad, A. J., \& Ibrahim, E. H. (2013). Effects of metacognitive listening strategy training on listening comprehension and strategy use of ESL leaners. World Applied Science Journal, 57-66.

Mbato, C. L. (2013). Facilitating EFL learners' self-regulation in reading: implementing a metacognitive approach in an Indonesian higher education context. PhD thesis. Lismore, NSW: Southern Cross University.

Mendelsohn, D. (1994). There ARE strategies for Listening. TEAL Occasional Papers, 8, 63-76. 
Mendelsohn, D. (1995). Applying learning strategies in the second/foreign language listening comprehension lesson. In Mendelsohn and Rubin (eds.). A Guide for the teaching of second language listening. San Diego: Dominie Press. 132-50.

Mendelsohn, D. (1998). Teaching listening. Annual Review of Applied linguistics. $18,3-19$.

O’Malley, J. M., Chamot, A. U., Stewnew-Mazanares, G., Russo, R, \& Kupper, L. (1985). Learning strategies applications with students of English as a second language. TESOL Quarterly, 19, 285-296.

O’Malley, J.M., \& Chamot, A. U. (1990). Learning strategies in second language acquisition. Cambridge: Cambridge University press.

Pammu, A., Amir, Z., \& Maasum, T.N. (2013). Metacognitive reading strategies of less proficient tertiary learners: a case study of EFL learners at a public university in Makasar, Indonesia. Procedia, 118, 357-364.

Pressley, M., \& L. W. Gaskins. (2006). Metacognitively competent reading comprehension is constructively responsive reading: How can such reading be developed in students? Metacognition learning, 1, 99-113.

Rahimirad, M. (2014). The Impact of Metacognitive Strategy Instruction on the Listening performance of University Students. Procedia, Social and Behavioral Sciences, 98, 1485-1491.

Rasouli, M., Mollakhan, K., \& Karbalaei, A. (2013). The effect of metacognitive listening strategy training on listening comprehension in Iranian EFL Context. European Online Journal of Natural and Social Sciences, 2 (1), 115-128.

Richards, J. C. (2008). Teaching listening and speaking. Cambridge: Cambridge university press.

Ridley, D. S., Schutz, P. A., Glanz, R.S., \& Weinstein, C.E. (1992). Self-regulated learning: the interactive influence of metacognitive awareness and goal setting. Journal of Experimental Education, 60, 293-306.

Rost, M. (2002). Teaching and researching listening. London: Longman.

Rost, M. (2005). L2 Listening. In Handbook of research on second language learning and teaching, pp: 503-527. Ed. Mahwah, NJ: Erlbaum.

Schraw, G. \& Moshman, D. (1995). Metacognitive theories. Educational psychology review, 7(4), 351-371.

Selamat, S., \& Sidhu, G. K. (2013). Enhancing Listening Comprehension: The Role of Metacognitive Strategy Instruction (MetSI). Procedia: Social and Behavioral Sciences, 90, 421-430.

Seo, K. (2002). The effects of visuals on listening comprehension: A study of Japanese learners' listening strategies. International Journal of Listening, $16,57-81$.

Thompson, I., \& Rubin, J. (1996). Can Strategy instruction improve listening comprehension? Foreign language Annals, 29, 331-342.

Van Zeeland, H., \& Schmitt, N. (2013). Incidental vocabulary acquisition through L2 listening: A dimensions approach. System, 41, 609-624.

Vandergrift, L \& Goh, C. (2012). Teaching and learning second language listening: Metacognition in action. New York: Routledge. 
Vandergrift, L. (2002). It was Nice to see that our predictions were right: developing Metacognition in L2 Listening Comprehension. The Canadian Modern Language Review, 58, 556-575.

Vandergrift, L. (2003). From prediction through reflection: Guiding students through the process of L2 listening. The Canadian Modern language Review, 59, 425-440.

Vandergrift, L. (2004). Learning to listen or listen to learn? Annual Review of Applied Linguistics, 24, 3-25.

Vandergrift, L., \& Tafaghodtari, H. M. (2010). Teaching L2 students how to listen does make a difference: An Empirical study. Language Learning, 60, 470497.

Vidal, K. (2011). A comparison of the effects of reading and listening on incidental vocabulary acquisition. Language Learning, 61(1), 219-258.

Wang, W. (2016). Learning to listen: the impact of a metacognitive approach to listening instruction. Asia-Pacific Educational Research: Springer, 25(1), 79-88.

Wenden, A. (1987). Metacognition: an expanded view of the cognitive abilities of L2 learners. Language Learning, 37, 573-594.

Zhang, D., \& Goh, C. (2006). Strategy Knowledge and perceived Strategy use: Singaporean Students' awareness of Listening and Speaking Strategies. Language Awareness, 15, 199-219. 